\title{
SPRY4 wt Allele
}

National Cancer Institute

\section{Source}

National Cancer Institute. SPRY4 wt Allele. NCI Thesaurus. Code C105083.

Human SPRY4 wild-type allele is located in the vicinity of 5q31.3 and is approximately 16 $\mathrm{kb}$ in length. This allele, which encodes protein sprouty homolog 4 , is involved in the negative regulation of signaling. 